\title{
Analysis Facilities, Customer Value on Passenger Satisfaction of Jakarta's Mass Rapid Transit (MRT) Train using the PLS Model
}

\author{
Salis Rabindra Ishaya ${ }^{1}$, Edi Wahyu Wibowo ${ }^{2}$, Yoeliastuti $^{3}$ \\ \{salis.ishaya@gmail.com ${ }^{1}$ \} \\ Politeknik LP3I Jakarta ${ }^{1,2,3}$
}

\begin{abstract}
On April 1, 2019, the Jakarta Mass Rapid Transit (MRT) Train has officially operated. Several problems have been complained by passengers, namely regarding the perception of ease of transactions and customer value, where these things are very important to meet customer satisfaction. This research uses PLS 3.0 software by analyzing the validity \& reliability test, as well as the $t$ test. The results of the analysis were obtained to test the validity and reliability of all of the values that were valid \& reliable. Meanwhile, the $t$ test shows that the variable customer value has a positive effect on passenger satisfaction. Likewise, the facilities variable has a positive effect on passenger satisfaction. Even though the results have been good, it is recommended that the MRT Jakarta Train Management can provide even better passenger satisfaction, such as providing facilities for persons with disabilities and need to add seats to wait and also integration packages with other transportation modes.
\end{abstract}

Keywords: Facilities, customer value, passenger satisfaction, MRT Jakarta

\section{Introduction}

Along with the times, in the present era, transportation is a necessity that cannot be separated from people's lives in carrying out their daily activities. Every company strives to provide the best service at a reasonable price for all its consumers (passengers) so that they feel satisfied with the services they consume and end up creating customer satisfaction [1].

On April 1, 2019, the Jakarta Mass Rapit Transit (MRT) Train has officially operated. Some of the problems complained by passengers, namely regarding customer facilities and value, where these things are very important to meet customer satisfaction. Customer satisfaction is the main focus or goal of PT. Mass Rapid Transit Jakarta in serving consumer needs. Satisfied consumers will continue to be loyal customers of PT. Jakarta's Mass Rapid Transit which can be used as a free promotional media for companies.

According to Nuryani, N. [2] in measuring the factors that affect passenger satisfaction, a standardized measuring device is needed, this is to ensure the consistency of measurement and the accuracy of the data collected. A standard measuring instrument must meet the psychometric criteria, namely validity and reliability. The questionnaire (measuring instrument / instrument) is generally a tool used to measure natural phenomena and observed social phenomena (Azwar, 2006). The questionnaire plays an important role in determining the quality of a study, because the validity of the data obtained will be largely determined by the quality of the questionnaire used, the data is a description of the variables studied and serves as a means of proving the 
hypothesis, so that the data does not depend on whether or not the questionnaire collects data (Djaali and Muljono, 2004). The validity and reliability study of the Japanese general nutrition knowledge questionnaire (JGNKQ) received a good validity test, the reliability test with the test-retest obtained a value of $r=0.75$ (Matsumoto et al., 2017). Research on the reliability of knowledge of nutrition in obese adolescent (KNOA) obtained cronbach $\alpha$ values $=0.788-0.807$ (Pinho et al., 2013). The quality of the questionnaire is determined by the validity (validity) and reliability (reliability) of a questionnaire (Emilia, 2008). Based on these descriptions, so that the purpose of this study is to assess the validity and reliability of the questionnaire on facility variables, customer value and passenger satisfaction in the Jakarta Mass Rapid Transit (MRT) Train [2].

\section{Literature Review}

\subsection{Customer satisfaction (train passenger)}

Customer satisfaction plays an important and critical role for the continuity and development of a company's life. By listening to consumers and then responding to their wishes or requests, it will provide more satisfying results and make consumers loyal. Previous research on train passenger satisfaction with the title "Analysis of the effect of punctuality, facilities and ticket prices on train passenger satisfaction at Purwosari Station" [3], the results show that timeliness, facilities, and ticket prices simultaneously have a positive effect. and significant to the passenger satisfaction of the Bengawan Train at Purwosari Station. Similar research on train passenger satisfaction with the title "The influence of trust factors, service quality, and facilities on train customer satisfaction"[4], the result is that trust has a positive and significant effect on customer satisfaction for economy class train transportation services. Service quality has a positive and significant effect on customer satisfaction in economy class transportation services. Facilities have a positive and significant effect on customer satisfaction for economy class train transportation services. The same research on train passenger satisfaction examines "The effect of facility accuracy, service quality and facilities on public satisfaction of mass train users (Mass Rapit Transit) across Surabaya Lamongan at Pasar Turi Surabaya Station, research results"[5]. namely Service Quality and Facilities have a positive effect on Customer Satisfaction in using the commuter train across Surabaya-Lamongan.

\subsection{Facilities}

Facilities are physical resources that exist before a service can be offered to consumers. Research on facilities with the title "The effect of facilities and service quality on customer satisfaction at Pertamina gas stations 54,612.64 in Sidoarjo" [6], the partial test results show that the facilities have a significant and positive effect on customer satisfaction who fill the ingredients. fuel at gas stations 54,612.64 Sidoarjo. Similar research on facilities examines "The effect of facilities on customer satisfaction at Aston Madiun Hotel \& Conference Center"[7], the results of the study stated that facilities have an influence on customer satisfaction. 


\subsection{Customer value}

According to Balqis (2009) [8] The value of penggan is a comparison between the benefits felt by the penggan and what the customer spends to get or consume the product / service. In his research Woro (2003) in the title "The effect of customer value and service quality on customer loyalty, through customer satisfaction on bus efficiency customers (PO Efficiency Study Yogyakarta-Cilacap Department)" the result is that customer value has a positive and significant effect on customer satisfaction. Another study on customer value entitled The effect of price, service quality and customer value on customer satisfaction at restaurants in the city of Purwokerto conducted by Wibowo (2013)[9], the result is that customer value has a positive and significant influence on customer satisfaction, while similar was done by Ikasari et al (2013)[10] entitled The Influence of Customer Value and Service Quality on Customer Satisfaction (Case Study of Kaligung Mas Passenger Train at Poncol Station Semarang). The result states that the Customer Value Variable has a positive influence on the Customer Satisfaction variable so that the hypothesis is accepted. These results prove that, satisfied respondents are caused by high Customer Value. Therefore, the higher (better) Customer Value generated, it will strengthen Customer Satisfaction with customers, and vice versa.

\section{Method}

\subsection{Types and research design}

This research is a descriptive study by testing the validity and reliability of the questionnaire on the facilities variable, customer value and passenger satisfaction of the Jakarta Mass Rapid Transit (MRT) Train. The research is quantitative, where the interpretation of research results is based on statistical processing using the PLS3.0 software application.

\subsection{Research time and location}

The research location was determined purposively. The research was conducted on passengers of the Jakarta Mass Rapid Train (MRT) Train. In July 2020.

\subsection{Samples}

The sampling technique used is the Accidental Sampling technique. According to Sugiyono (2008: 92) states that Accidental Sampling is a sampling technique based on chance, that is, anyone who happens to meet the researcher can be used as a sample, if it is considered that the person who happened to be met is suitable as a source of data. These respondents are passengers of the Jakarta Mass Rapid Transit (MRT) Train and are willing to be respondents. The sample in this study were 100 passengers of the Jakarta Mass Rapid Train (MRT) Train.

\subsection{Research variables $\&$ indicators}

Measurement of research data includes research variables, namely Customer Value, Facilities, and Passenger Satisfaction. The entire questionnaire on each variable consists of a 
score of $5=$ Strongly Agree, Score $4=$ Agree, Score $3=$ Agree, Score $2=$ Disagree, Score $1=$ Strongly Disagree. While the research indicators are as follows:

3.4.1 Facilities (X1) are all things that can facilitate and facilitate the implementation of all business. The indicators of the facilities are:

- Availability of parking space for 2 or 4 wheeled vehicles (F1)

- Availability of seats in the passenger waiting room (F2)

- Availability of free toilets (F3)

- Availability of prayer rooms or places of worship (F4)

- Availability of supporting facilities such as free cellphone chargers, stairs going up / down for passengers(F5)

3.4.2 Customer Value (X3) according to Monroe in Ikasari (2013)[10] suggests that Customer Value is a trade off between customer perceptions of the quality or benefits of a product and sacrifices made through the price paid. So that the indicators of ease of transaction are:

- Has added value (N1)

- Cost-benefit (N2) compatibility

- Ease of obtaining services (N3)

- Emotional Value (N4)

3.4.3 The dependent variable $(Y)$ or the dependent variable in this study is passenger satisfaction. Consumer satisfaction is the level of consumer feelings after comparing what he received with what was expected. The intended consumers are train passengers. Indicators of passenger satisfaction are:

- Satisfaction with train timeliness (K1)

- Satisfaction with the completeness of the facilities (K2)

- Satisfaction with price suitability (K3)

- Satisfaction with train departure schedules (K4)

- Satisfaction with the function of the facility (K5)

\subsection{Sources, data collection and processing methods}

This study uses primary data, namely the measurement and collection of data directly by the researcher using a questionnaire. The questionnaire was filled in by filling it out directly by the research subject.

\subsection{Data analysis}

Data analysis using the PLS 3.0 application with the following Table 1: 
Table 1. Measurement standards for validity \& reliability test

\begin{tabular}{|l|l|l|}
\hline Validity Test & \multicolumn{1}{|c|}{ Parameter } & \multicolumn{1}{c|}{ Rule of Thumbs } \\
\hline Convergent & Outer Loading & $>0.7$ \\
\hline & Average Variance Extracted (AVE) & $>0.5$ \\
\hline Discriminant & Akar AVE dan Korelasi Variabel Laten & $\begin{array}{l}\text { The value of AVE> R2 is the } \\
\text { highest than endogenous } \\
\text { variables }\end{array}$ \\
\hline & Cross Loading & $>0.7$ into variables \\
\hline & \multicolumn{1}{|c|}{ Parameter } & \multicolumn{1}{c|}{ Rule of Thumbs } \\
\hline Reliability Test & \multicolumn{1}{|c|}{0.6} \\
\hline & Cronbach's Alpha & $>0.6$ \\
\hline & Composite Reliability & \multicolumn{1}{|c|}{} \\
\hline
\end{tabular}

$\mathrm{T}$ test (partial test), which is to test whether the independent variable individually affects the dependent variable.

Accept Ho if $t$ count $<t$ table $(\alpha=0,05)$

Accept Ha if $\mathrm{t}$ count $>\mathrm{t}$ table $(\alpha=0,05)$

\section{Results and Discussion}

\subsection{Results}

\subsubsection{Validity \& reability test}

Based on the analysis using PLs 3.0 software, the results of validity and reliability are as follows Figure 1:

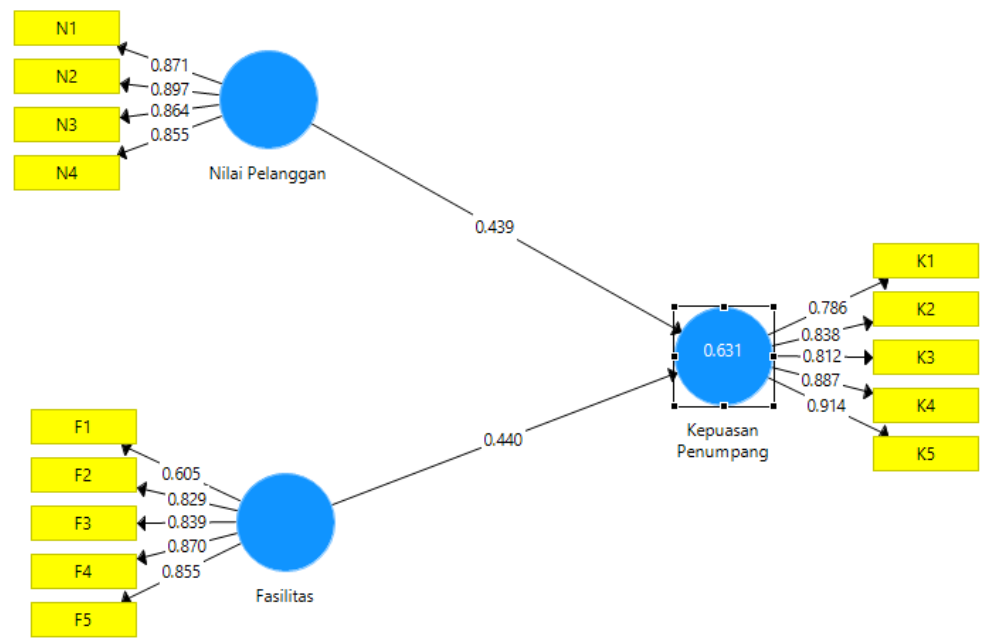

Fig. 1. PLS SEM model 1 facility, customer value and passenger satisfaction variables Jakarta MRT 


\subsubsection{Validity test (convergent analysis)}

\subsection{Outer loading}

From Figure 1, the outer loading results are obtained as follows Table 2:

Table 2. Outer loading results

\begin{tabular}{|l|r|r|r|}
\hline & Fasilitas & Kepuasan Pen... & Nilai Pelanggan \\
\hline F1 & 0.605 & & \\
\hline F2 & 0.829 & & \\
\hline F3 & 0.839 & & \\
\hline F4 & 0.870 & & \\
\hline F5 & 0.855 & & \\
\hline K1 & & 0.786 & \\
\hline K2 & & 0.838 & \\
\hline K3 & & 0.812 & \\
\hline K4 & & 0.887 & \\
\hline K5 & & 0.914 & \\
\hline N1 & & & 0.871 \\
\hline N2 & & & 0.897 \\
\hline N3 & & & 0.864 \\
\hline N4 & & & 0.855 \\
\hline
\end{tabular}

According to the measurement standards in Table 1, outer loading must be worth more than 0.7 , from the results of Table 2, it is found that only the F1 Indicator / Instrument is 0.605 or below 0.7 so that this indicator / instrument must be removed / removed to get valid results. So that the latest results will be obtained as shown in Figure 2 as follows:

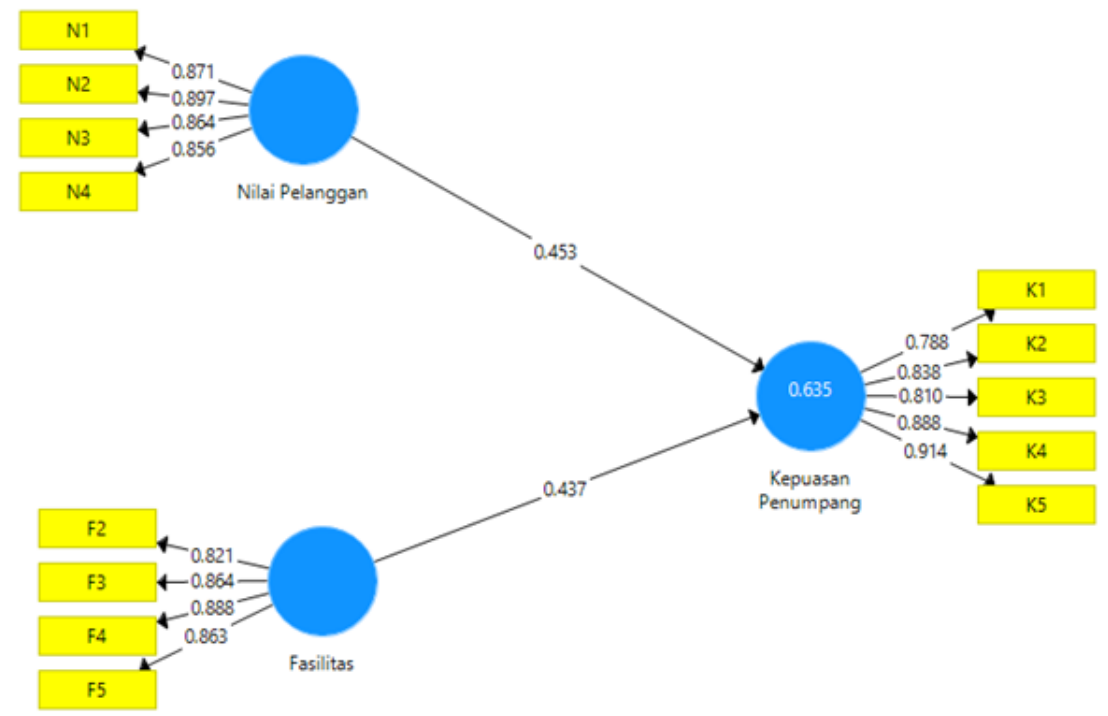

Fig. 2. PLS SEM model 2 facility, customer value and passenger satisfaction variables 


\subsection{Average variance extracted (AVE)}

Table 3. Result of average variance extracted

\begin{tabular}{|l|r|}
\hline \multicolumn{1}{|c|}{} & Average Variance Extracted (AVE) \\
\hline Fasilitas & 0.739 \\
\hline Kepuasan Penumpang & 0.720 \\
\hline Nilai Pelanggan & 0.760 \\
\hline
\end{tabular}

According to the standard measurement in Table 1, the Average Variance Extracted (AVE) must be worth more than 0.5 , from the results of Table 3 it is found that the facility variables, customer value and passenger satisfaction are all above 0.5 so the results can be said to be valid.

\subsubsection{Validity test (discriminant analysis)}

\subsection{AVE roots and latent variable correlation}

Table 4. Result of R square

\begin{tabular}{|c|r|r|} 
& R Square & R Square Adjus... \\
\hline Kepuasan Penumpang & 0.635 & 0.628 \\
\hline
\end{tabular}

According to the standard measurement in Table 1, the Average Variance Extracted (AVE) result (Table 3) must be greater than the $\mathrm{R}$ Squere result (Table 4). The results of the analysis obtained that all variables (facilities, customer value, passenger satisfaction) produce an Average Variance Extracted (AVE) with a value greater than the R Square, which is 0.635 , so the results can be said to be valid.

\subsection{Cross loading}

Table 5. Result of Cross Loading

\begin{tabular}{|l|r|r|r|}
\hline & Fasilitas & Kepuasan Penumpang & Nilai Pelanggan \\
\hline F2 & 0.821 & 0.553 & 0.429 \\
\hline F3 & 0.864 & 0.553 & 0.499 \\
\hline F4 & 0.888 & 0.655 & 0.602 \\
\hline F5 & 0.863 & 0.668 & 0.540 \\
\hline K1 & 0.482 & 0.788 & 0.498 \\
\hline K2 & 0.694 & 0.838 & 0.562 \\
\hline K3 & 0.671 & 0.810 & 0.682 \\
\hline K4 & 0.521 & 0.888 & 0.615 \\
\hline K5 & 0.611 & 0.914 & 0.658 \\
\hline N1 & 0.535 & 0.575 & 0.871 \\
\hline N2 & 0.552 & 0.626 & 0.897 \\
\hline N3 & 0.522 & 0.618 & 0.864 \\
\hline N4 & 0.509 & 0.674 & 0.856 \\
\hline
\end{tabular}


According to the standard measurement in Table 1, the Cross Loading results from all the results of each variable (facilities, customer value, passenger satisfaction) must be a value above or more than 0.7. From the result of the Cross Loading analysis (Table 5), all variables have a value above 0.7 so that the results can be said to be valid.

\subsubsection{Reliability test (cronbach's alpha analysis)}

Table 6. Cronbach's Alpha results

\begin{tabular}{|l|c|}
\hline & Cronbach's Alpha \\
\hline Fasilitas & 0.882 \\
\hline Kepuasan Penumpang & 0.903 \\
\hline Nilai Pelanggan & 0.895 \\
\hline
\end{tabular}

According to the standard measurement in Table 1, the Cronbach's Alpha results from the results of each variable (facilities, customer value, passenger satisfaction) must be a value above or more than 0.6. From the results of the analysis of Cronbach's Alpha (Table 6), all variables have a value above 0.6 , so the results can be said to be reliable.

\subsubsection{Reliability test (composite reliability analysis)}

Table 7. Composite reliability results

\begin{tabular}{|l|r|}
\hline \multicolumn{1}{l|}{} & Composite Reliability \\
\hline Fasilitas & 0.919 \\
\hline Kepuasan Penumpang & 0.928 \\
\hline Nilai Pelanggan & 0.927 \\
\hline
\end{tabular}

According to the standard measurement in Table 1, the Composite Reliability results from the results of each variable (facilities, customer value, passenger satisfaction) must be a value above or more than 0.6. From the results of the Composite Reliability analysis (Table 7), all variables have a value above 0.7 , so the results can be said to be reliable.

\subsubsection{The $t$ test}

Table 8. Results of the t test

\begin{tabular}{|l|r|r|rr|r|r|}
\hline \multicolumn{1}{l|}{} & Original Sample $(0)$ & Sample Mean $(M)$ & Standard Deviation (STDEV) & TStatistics $($ OO/STDEV) & P Values \\
\hline Fasilitas $>$ Kepuasan Penumpang & 0.437 & 0.438 & 0.078 & 5.616 & 0.000 \\
\hline Nilai Pelanggan $>$ Kepuasan Penumpang & 0.453 & 0.454 & 0.085 & 5.318 & 0.000 \\
\hline
\end{tabular}

From Table 8, it can be seen that:

- The effect of the facilities variable on passenger satisfaction $\mathrm{t}$ count 5,616>t table $=1,664$, Ho is rejected, Ha is accepted

so that the transaction ease variable has a positive effect on passenger satisfaction 
- The influence of customer value variables on passenger satisfaction $\mathrm{t}$ count $5,318>\mathrm{t}$ table $=1,664$, Ho is rejected, $\mathrm{Ha}$ is accepted

so that the Customer Value variable has a positive effect on passenger satisfaction

\subsection{Discussion}

From the results of data analysis, the results of validity and reliability tests are good for each variable indicator, namely:

\subsubsection{Validity \& reliability test}

From the validity and reliability test on the variable indicator of customer value, the variable of facilities and the variable of passenger satisfaction, the results are valid \& reliable.

\subsubsection{T test}

From the $t$ test analysis, it is found that the customer value variable has a positive effect on the passenger satisfaction variable of the MRT Jakarta Train. This is similar to the results of previous research conducted by Wibowo (2013) [9], the result is that customer value has a positive and significant effect on customer satisfaction, while the same research was conducted by Ikasari et al. [10] The results state that the Customer Value variable has a positive influence on the variable Customer Satisfaction so that the hypothesis is accepted.

Likewise, the facilities variable has a positive effect on the train passenger satisfaction variable. The results of research on the effect of facilities on passenger satisfaction of the Jakarta Integrated Moda Raya (MRT) Train are similar to those conducted by Srijani [7], the results of the study state that facilities have an influence on customer satisfaction. Research with the same results was also carried out by Toriq [6]. The partial test results showed that facilities had a significant and positive effect on customer satisfaction who did refueling.

\section{Conclusion}

In this study, to test the validity \& reliability of all variable indicators produced valid \& reliable values. From the $t$ test analysis, it is found that the variable customer value has a positive effect on the passenger satisfaction variable of the MRT Jakarta Train. Likewise, the facilities variable has a positive effect on the train passenger satisfaction variable. Even though the results have been good, it is recommended that the MRT Jakarta Train Management can provide even better passenger satisfaction, such as providing facilities for persons with disabilities and need to add seats to wait and also integration packages with other transportation modes.

\section{References}

[1] Mardhino, R., \& Yulhendri, Y. (2019). Pengaruh Harga Dan Pelayanan Terhadap Kepuasan Penumpang Transportasi Darat KA Sibinuang Jurusan Padang-Pariaman. Jurnal Ecogen, 2(4), 643 653. 
[2] Nuryani, N. (2019). Validitas dan Reliabilitas Kuesioner Pengetahuan, Sikap dan Perilaku Gizi Seimbang Pada Remaja. Ghidza: Jurnal Gizi dan Kesehatan, 3(2), 37-46.

[3] Apriyadi, D. (2017). Analisis pengaruh ketepatan waktu, fasilitas dan harga tiket terhadap kepuasan penumpang kereta api di stasiun purwosari. Jurnal Magistra

[4] Susanti, Desi.2017. Pengaruh faktor kepercayaan, kualitas layanan, dan fasilitas terhadap kepuasan pelanggan kereta api. Jurnal Ilmu dan Riset Manajemen. STIESIA

[5] Budianto, Aris. 2014. Pengaruh Ketepatan waktu, kualitas pelayanan dan fasilitas terhadap kepuasan masyarakat pengguna kereta api masal cepat Surabaya. Jurnal Ilmu Administrasi Negara Surabaya

[6] Toriq, Muhammad. 2014. Pengaruh fasilitas dan kualitas layanan terhadap kepuasan penggan pada SPBU Pertamina 54.612.64 Sidoarjo. Jurnal Ilmu Riset Manajeman Surabaya

[7] Srijani, Ninik \& Achmad Sukma Hidayat. 2017. Pengaruh fasilitas terhadap kepuasan pelanggan di Aston Madiun Hotel \& Conference Center. Jurnal Penelitian Ilmu Ekonomi WIGA

[8] Woro, M., \& Naili, F. (2013). Pengaruh nilai pelanggan dan kualitas layanan terhadap loyalitas pelanggan, melalui kepuasan pelanggan pada pelanggan bus efisiensi (Studi PO Efisiensi Jurusan Yogyakarta-Cilacap). Jurnal Administrasi Bisnis, 2(1).

[9] Wibowo, A. S. (2013). Pengaruh harga, kualitas pelayanan dan nilai pelanggan terhadap kepuasan konsumen pada rumah makan di Kota Purwokerto (Doctoral dissertation, Universitas Negeri Semarang).

[10] Ikasari, A. U., Suryoko, S., \& Nurseto, S. (2013). Pengaruh Nilai Pelanggan dan Kualitas Pelayanan terhadap Kepuasan Pelanggan (Studi Kasus pada Penumpang KA Kaligung Mas di Stasiun Poncol Semarang). Jurnal Ilmu Administrasi Bisnis, 52-59. 